\title{
SHIFTING THE MEANING OF SEMBUR UTIK IN DELIVERING JENAZAH TO THE CITY IN WONOSOBO
}

\author{
PERGESERAN MAKNA SEMBUR UTIK DALAM PENGANTARAN JENAZAH \\ KE KUBURAN DI WONOSOBO
}

\author{
Lutfiyatul Hasanah \\ Guru Sejarah SMPK Muncar \\ lutfiyahasanah@gmail.com \\ (*) Corresponding Author \\ +62 813-3370-0507
}

How to Cite: Hasanah (2019). Title of article. Santhet, 3(2), 56- 63

doi:

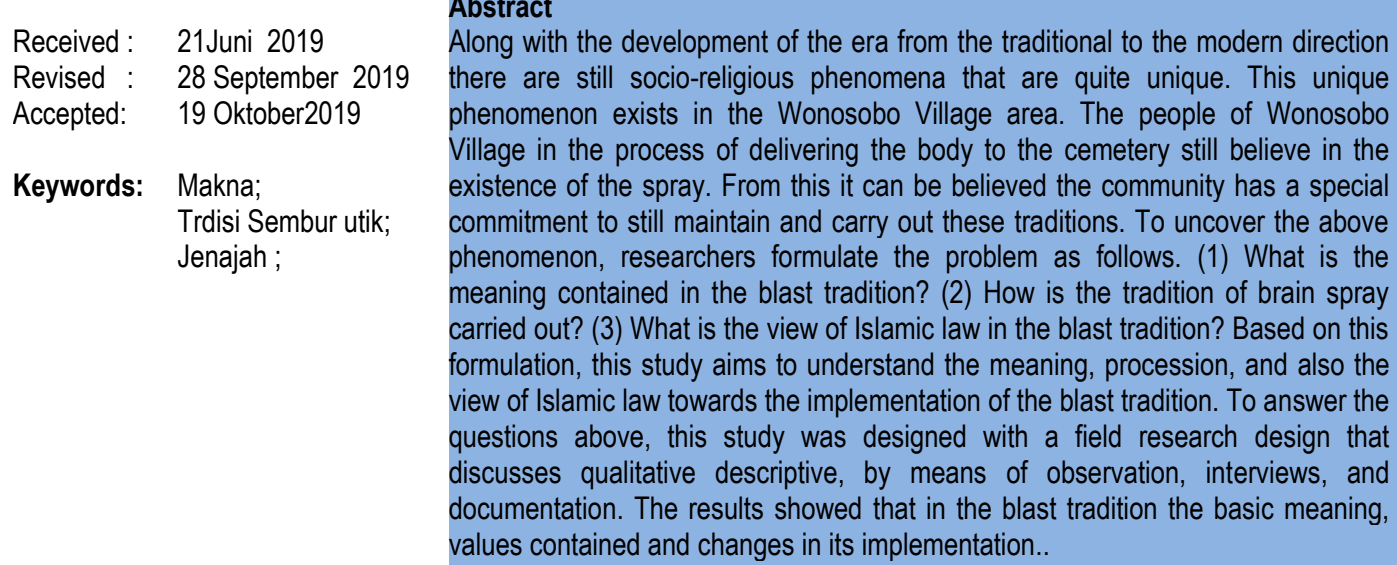

\section{PENDAHULUAN}

Banyuwangi merupakan kabupaten yang memiliki keberagaman budaya, adat istiadat serta tradisi. Dalam sejarah kehidupan sosial budaya, Banyuwangi yang merupakan wilayah multikultural dikenal dengan adanya berbagai tradisi yang memiliki makna simbolik dan konsepsi masing-masing. Masyarakat memiliki tradisi/ritus unik terkait dengan daur hidup mereka, mulai dari lahir, kanak-kanak, remaja, nikah, hingga kematian (Van Gennep, 2006: 203). Dalam konteks ini, bahwa ritual di seputar kematian seseorang di Jawa juga menjadi salah satu tradisi yang unik. Upacara tersebut dilakukan oleh orang Jawa dalam usahanya menjaga keseimbangan antara alam kodrati dan alkodrati. Sistem upacara hidup juga berangkat dari sistem religi masyarakat Jawa.

Tradisi dan Budaya adalah darah daging dalam tubuh masyarakat dimanapun berada. Namun sekarang ini, yakni era modern banyak yang tidak menggunakan lagi upacara atau tata cara tersebut dengan berpendapat bahwa hal-hal tersebut tidak memiliki faedah dan berfaham kekunoan apabila masih mengikutinya. Akan tetapi masih banyak juga yang mempertahankan cara-cara tradisional, tata cara atau adat untuk dilakukan, karena mereka berpendapat bahwa hal-hal tersebut mengandung maksud dan arti yang memang harus dilakukan demi kebaikan. Sama halnya penggunaan sembur utik dalam pengantaran jenazah ke kuburan. 
Dewasa ini, dalam pengantaran jenazah ke kuburan tidak lagi menggunakan istilah"kereta manusia" dalam artian tidak lagi menggunakan keranda dengan dipikul manusia, melainkan sudah memanfaatkan teknologi modern yakni menggunakan ambulance atau mobil kematian. Dengan penggunaan mobil jenazah saat mengantarkan jenazah ke kuburan menjadikan tidak adanya lagi penggunaan sembur utik dalam pengantaran jenazah ke kuburan. Padahal dalam masyarakat, sembur utik sendiri memiliki makna filosofis. Meskipun sebagian ulama berpandangan bahwa sembur utik tidak diperbolehkan karena cenderung bersifat memubazirkan barang.

Melihat realitas tersebut, timbullah kegelisahan peneliti untuk mengetahui hal apa yang menjadi alasan masyarakat di Desa Wonosobo ini melakukan ritual tersebut. Oleh karena itu dalam penelitian ini penulis ingin membahas dan meneliti apa saja alasan yang mendasari ritual atau tradisi ini. Dengan maksud penulis memperkaya khazanah adat dan budaya mayarakat. Untuk itu penulis mengambil judul "Pergeseran Makna Sembur Utik dalam Pengantaran Jenazah ke Kuburan di Wonosobo".

Dengan demikian peneliti ingin mengetahui sebagai berikut. Pertama peneliti ingin mengetahui prosesi pelaksanaan tradisi sembur utik. Kedua makna yang terkandung dalam pelaksanaan tradisi sembur utik. Ketiga, peneliti ingin mengetahui pandangan hukum islam terhadap tradisi sembur utik.

Oleh karena itu, hasil dari penelitian mengenai pergeseran makna sembur utik dapat memberi gambaran mengenai prosesi, makna dalam pelaksanaan tradisi sembur utik serta untuk memahami terjadinya pergeseran makna tradisi tersebut. Disisi lain kajian ini juga memberi informasi yang jelas serta agar dapat memperkaya khasanah pengetahuan tentang ada tidaknya Pergeseran makna sembur utik dalam pengantaran jenazah ke kuburan di Wonosobo.

Dalam hal ini peneliti menggunakan jenis makna deskriptif (descriptive meaning) yang mana peneliti mendeskripsikan makna kata atau istilah yang digunakan dalam penelitian serta makna yang berlaku dalam masyarakat, sebagaimana Pateda (2001:99) menyatakan bahwa makna deskriptif ialah makna yang terkandung dalam kata itu pada masa sekarang atau makna yang berlaku dalam masyarakat sebagai pengguna atau pemakai bahasa itu sendiri.

Sebuah makna akan mengalami perubahan tatkala adanya suatu bentuk pergeseran yang diakibatkan oleh berbagai hal seperti halnya pengucapan atau pelafalan, tambahan kata asing, plesetan, faktor sosial dan lain sebagainya seabagaimana Ulmann dalam Mansoer Pateda (2001:162) menyatakan bahwa : (1) Bahasa Itu berkembang, atau bahasa itu diturunkan dari generasi ke generasi. Dalam perkembangan ini makna kata-kata tertentu mengalami perubahan; (2) Makna kata sendiri itu kabur, samar-samar maknanya.; (3) kehilangan motivasi (loos of motivation); (4) Adanya kata-kata yang bermakna ganda (polysemy);(5) Dalam konteks yang membingungkan (in ambiguous contexts); (6) Struktur kosa kata".

Kematian (ajal) adalah hal yang pasti terjadi pada setiap makhluk yang bernyawa, tidak ada yang mengetahui kapan dan dimana ia akan menemui ajal, dalam keadaan baik atau buruk. Bila ajal telah tiba tidak ada yang dapat memajukan ataupun mengundurkannya (Afnan Chafidh, 2007:178). Sebagaimana Jamil menegaskan bahwa Menurut kenyakinan Islam orang yang sudah meninggal dunia ruhnya tetap hidup dan tinggal sementara di alam kubur atau alam barzah, sebagai alam antara sebelum memasuki alam akhirat tanpa kecuali, apakah orang tua ataupun anak-anak" (2002:127).

Tradisi ialah kebiasaan yang turun menurun dari sebuah masyarakat. la merupakan kesadaran kolektif sebuah masyarakat. Sifatnya luas sekali, meliputi segala kompleks kehidupan sehingga sukar disisih-sisihkan dengan pemerincian yang tetap dan pasti. Terutama sulit sekali diperlakukan serupa, itu karena tradisi itu bukan objek yang mati, melainkan alat yang 
hidup untuk melayani manusia yang hidup pula. la bisa disederhanakan, tetapi kenyataanya tidak sederhana (Rendra, 1984:3). Tradisi, dalam hal ini, terkait juga dengan interpretasi sebuah masyarakat dalam melihat realitas untuk disikapi dengan keyakinan dan kepercayaan. Tradisi terbentuk dari mitos, legenda, epos, sejarah nyata yang pernah terjadi, maupun refleksi seorang tokoh atas kehidupan yang saat itu sedang menjadi persoalan. Wujud tradisi itu sendiri sangat bermacam-macam. Mulai dari upacara keagamaan, upacara pernikahan, upacara kematian, upacara kelahiran, perayaan hari-hari tertentu, maupun tradisi dalam wujud kesenian (Suwito, 2015:199).

Ketika tentang perawatan jenazah sudah dilaksanakan semua yakni memandikan, mengkafani, mensolatkan hendaklah dengan segera jenazah dibawa ke pemakaman. Sebagaimana telah kita ketahui bahwasannya tentang keutamaan jenazah dan apa yang mengikutinya itu ada pahala yang banyak; yaitu bagi orang yang mengantar dan mengikutinya sampai dikuburkan-nya (Ayub Mursalin, 2004:211).

Menurut mbah Untung nama sembur utik berasal dari sembur yang berarti menyemburkan dengan menggunakan tangan dan utik yang berarti di utak utik. Jadi asal kata sembur berarti disembursemburkan dengan menggunakan tangan. Sebenarnya sembur berarti menyebarkan, menyebarkan yang dimaksud disini adalah menyebarkan amalan atau kebaikan dan ketika menyemburkan sebenarnya harus menggunakan shalawat atas nabi yaitu Allahumma sholli'ala muhammad.

Sembur jika dalam bahasa Indonesia adalah menyembur. Istilah sembur dalam kamus Besar Bahasa Indonesia Sembur1/sembur/n apa yang dipancarkan (disemprotkan) dari mulut. Menyembur/me•nyem•bur/v : 1 memancar atau menyemprotkeluar cepat-cepat; 2 memancarkan sesuatu (pada);memerciki dengan air (yang sudah dimantrai dan sebagainya)Menyemburi/me•nyem•buri/1

Smemancarkan sesuatu (pada);
menyemprotkan sesuatu (pada); 2 mengobati atau mengusir roh jahat dengan sembur; memerciki dengan air (yanng sudah dimantrai dan sebagainya). Sedangkan kata utik sendiri memiliki arti sebagai berikut : meng•utik-utik v1 menyentuhnyentuh; mengusik-usik; menyinggungnyinggung Sembur utik adalah proses tradisi yang dilakukan dalam pengantaran jenazah dengan isian beras kuning, bunga, serta uang yang disemburkan selagi jenazah di hantarkan ke kuburan.

Dapat ditegaskan bahwa Sembur Utik merupakan sesaji yang ditaburkan saat arakarakan, yang terdiri dari beras kuning dicampur dengan uang receh yang berjumlah ganjil. Biasanya berjumlah Rp. 99.000 (Sulistyani, 2015 : 34). Namun pelaksanaan ritual sembur utik dalam prosesi pengantaran jenazah berbeda dengan adanya dalam arak-arakan. Dalam prosesi pengantaran jenazah isian sembur utik sama- sama berisi beras kuning, uang yang tidak ditentukan jumlahnya, serta bunga

\section{METODE PENELITIAN}

Desa Wonosobo merupakan sebuah Desa yang masih memegang teguh suatu adat atau tradisi terkait dengan daur hidup manusia, seperti halnya jaran kecak sebagai suatu tradisi dalam khitan, kosek punjen dalam tradisi pernikahan sampai tradisi sembur utik dalam tradisi pengantaran jenazah ke kuburan. Oleh karena itu peneliti ingin meneliti daerah tersebut. Penentuan responden penelitian dilakukan secara purvosive, yaitu informan yang di wawancara dalam penelitian ini adalah orang-orang yang memiliki wawasan dan pengetahuan mengenai topik penelitian sehingga dapat memberikan informasi yang selengkap-lengkapnya dan dijadikan subjek penelitian dapat di pertanggungjawabkan. Selain itu, informan juga ditentukan dengan teknik snowball sampling, yakni proses penentuan informan berdasarkan informan atau responden sebelumnya tanpa menentukan jumlahnya secara pasti dengan menggali informasi terkait topik penelitian yang diperlukan (Nugraha, 2005:3). Adapun yang responden penelitian adalah pemangku adat, masyarakat Desa Wonosobo dan pemuka agama. 
Pada penelitian ini dalam pengambilan data menggunakan tiga cara pengumpulan data yakni teknik observasi, teknik wawancara, dan teknik dokumentasi. Dalam penelitian ini menggunakan teknik observasi non partisipan, yaitu peneliti melakukan pengamatan secara langsung dengan posisi sebagai pengamat (peserta pasif) bukan sebagai pelaku/peserta aktif (Suprayogo, 2001).

Dalam hal ini peneliti menggunakan metode interview bebas terpimpin yaitu merupakan perpaduan antara interview terpilih dan interview tak terpimpin sehingga data yang diperoleh diharapkan akan lebih lengkap dan mendalam. Teknik pengambilan data yang lain adalah dokumentasi ini digunakan oleh peneliti sebagai alat untuk mengumpulkan data baik dalam bentuk gambar ataupun suara yang nantinya akan dipergunakan sebagai bahan bahasan dalam penulisan.

Model analisis yang digunakan dalam penelitian ini adalah analisis interaktif (Bimo Walgito, 2005:65). Proses analisis data sudah dilakukan sejak awal bersamaan dengan pengumpulan data awal dari penelitian ini. Selanjutnya data yang diperoleh tersebut dikomparasikan secara interaktif antara reduksi data, sajian data dan untuk selanjutnya akan diperoleh suatu simpulan dari hasil penelitian berupa model interaktif pengumpulan sumber sebagai berikut, kegiatan analisis interaktif sebagai berikut : pertama Reduksi data, kedua sajian data, dan yang terakhir reduksi data

\section{HASIL DAN PEMBAHASAN}

Setiap tradisi atau adat pasti memiliki asal-usul atau sejarah adanya tradisi tersebut, namun dalam hal ini dari hasil penelitian yang dilakukan oleh peneliti mengenai tradisi sembur utik ini tidak banyak yang tahu asal usulnya dari mana. Mereka hanya melakukan sesuai apa yang mereka ketahui dari generasi sebelumnya. Padahal dalam hal apapun, termasuk sebuah tradisi wajib di fahami terlebih dahulu mengenai asal usulnya agar untuk diturunkan ke generasi penerus tidak terjadi salah kaprah baik dalam hal pelaksanaan maupun pemaknaannya. Dengan tidak adanya yang tahu asal usul tradisi sembur utik ini, generasi muda hanya melaksanakan apa yang ia ketahui tanpa ia fahami. Pelaksanaannya pun hanya berdasarkan apa yang di lihat, entah itu ada perubahan atau tidak mereka tidak mau tahu akan hal itu, yang terpenting mereka hanya melakukan atas dasar itu hanyalah sebuah tradisi yang wajib dilaksanakan, tanpa tahu asal usulnya darimana dan memiliki maksud apa.

Adapun prosesinya yang pertama, Membuat beras kuning, yang terbuat dari beras biasa dan parutan kunyit, kedua mengaduk parutan kunyit dan beras, ketiga mencampurkan uang receh (logam) ke dalam wadah beras kuning, keempat mencampurkan bunga, kelima ketika jenazah diberangkatkan, pembawa sembur utik ada didepan keranda jenazah, ke tujuh menyemburkan sembur utik di depan rumah sampai pada makam. Namun berbeda pelaksanaannya ketika pengantaran jenazah dilakukan dengan menggunakan mobil jenazah, sembur utik terkadang dilakukan namun terkadang juga tidak dilaksanakan.

Adapun jika melaksanakannya pun pembawa sembur utik tetap berada didepan mobil jenazah, namun jika tidak sembur utik tidak dilaksanakan dan hanya diletakkan diatas makam. Upacara daur hidup manusia terkait dengan masalah tradisi dalam kehidupan masyrakat Jawa pada umumnya masih dipegang teguh, namun dalam era modern yakni perkembangan pola pikir, perkembangan ilmu dan tekhnologi pada manusia menjadikan sebuah tradisi itu luntur baik dari segi substansi maupun fungsi. Hal ini disebabkan kecenderungan pola fikir manusia yang semakin berorientasi dan berfikir praktis dalam berkehidupan.

Dewasa ini pola hidup manusia memang mengalami perkembangan menjadi lebih modern, namun dalam upacara daur hidup yakni pada suatu tradisi mengalami penyederhanaan-penyederahanaan baik sarana maupun prosesinya. Kebanyakan pada masyarakat sekarang ini sudah tidak tahu lagi prosesi lengkap dan tata cara serta 
sarana utuh dalam penyelenggaraan suatu tradisi, seperti halnya tradisi sembur utik.

Dalam pelaksanaannya kini sudah jarang diketahui lagi, karena banyak yang kini menggunakan teknologi atau memanfaatkan kemajuan tekhnologi. Pengantaran jenazah ke kuburan misalnya, di era sekarang lebih banyak menggunakan jasa transportasi mobil kematian dibandingkan dengan memikul dengan menggunakan keranda. Dengan alasan penggunaan mobil kematian lebih praktis dan lebih efisien dibandingkan harus menggunakan keranda dan dipikul oleh manusia. Penggunaan jasa mobil kematian menjadikan prosesi tradisi sembur utik tidak dilaksanakan sebagaimana mestinya, walaupun sembur utik masih dipergunakan.

Berdasarkan pengamatan peneliti tradisi sembur utik ini yang terdiri dari beras kuning dan uang receh/uang logam serta bunga boleh diuat oleh siapa saja, namun biasanya dibuat oleh seseorang yang di tuakan atau yang dianggap sesepuh. Sesepuh disini yang dimaksudkan adalah sesorang perempuan yang sudah tidak mengalami masa menstruasi atau orang yang bersih.

Bahan ubo rampe yang digunakan untuk membuat sembur utik adalah sebagai berikut : (1) Beras Kuning, adapun cara pembuatan beras kuning ini yaitu yang pertama mengambil beras kering, dan tidak di cuci karena jika dicuci takutnya beras akan lengket satu sama lain. Kemudian ambil kunyit secukupnya dan diparut, selanjutnya kunyit yang telah di parut tadi di campurkan dengan beras kuning sampai merata. (2) Uang Receh, Uang receh yang digunakan adalah uang logam seratusan, dua ratusan, lima ratusan maupun seribuan. Uang receh ini mengandung makna bahawa uang ini sebagai saksi adanya sandang. (3) Bunga, bunga bermakna filosofis agar yang hidup senantiasa mendapatkan keharuman dari para leluhur. Keharuman merupakan kiasan dari berkah syafaat yang berlimpah dari para leluhur dapat mengalir kepada anak turunnya. Namun di era sekarang banyak generasi yang tidak mengetahui apa makna dari masing-masing ubo rampe dalam sebuah tradisi merupakan hal penting yang wajib diketahui, baik makna maupun kelengkapannya. Karena apabila tidak faham dengan makna dari ubo rampe tersebut bisa saja menggunakan dengan seenaknya serta menjadikan kesalahan dalam mengartikannya. Contoh saja salah satunya makna bunga dalam ubo rampe sembur utik, ternyata bunga dalam sembur utik memiliki makna filosofis yang bisa dijadikan sebagai pemahaman bagi manusia.

Dalam pembawaan sembur utik sebenarnya siapapun boleh membawanya, yang diutamakan adalah seorang laki-laki yang memiliki badan sehat dan kuat. Karena diutamakan dalam pengantaran jenazah dilakukan dengan jalan cepat agar cepat sampai. Posisi pembawa sembur utik ada tepat pada depan keranda mayit, karena dilihat dari fungsinya bahwa beras kuning bukan hanya melambangkan keselamatan, tetapi juga sebagai tebusan jalan untuk si mayit. Namun jika jenazah di usung dengan mobil jenazah biasanya sembur utik itu ada, terkadang ada yang tidak ada. Kalaupun ada yang membawa juga harus menaiki kendaraan, jadi tidak bisa hanya orang satu, harus orang dua karena yang satu membawa sembur utiknya yang satu menyetir motornya.

Penyebaran beras kuning atau sembur utik berjalan dan membunyikan lafadz laa ilaa haillallah sampai ke makam, sambil menyemburkan beras kuning sampai ke makam dan biasanya beras kuning harus habis disemburkan. Ketika menyemburkan sambil membaca shalawat, Allahumma sholli ala muhammad.

Sebenarnya apabila sembur utik tidak dilaksanakan sebenarnya tidak apa-apa, namun karena itu adat atau tradisi maka harus dilaksanakan dan wajib ada dalam pelaksanaannya. Arus globalisasi dan perubahan pola pikir manusia membawa pergeseran dalam sistem tata cara dan upacara tradisi. Salah satunya adalah pergeseran makna sembur utik dalam pengantaran jenazah, dari hanya pelaksanaan yang seharusnya bersifat simbolis menjadi kepercayaan yang bersifat magis hal ini terbukti adanya perubahan dalam hal pemfungsian, sembur utik yang 
harusnya hanya digunakan dalam pengantaran jenazah sebagai simbol atau lambang untuk penebusan jalan dan keselamatan malah dijadikan sebagai keyakinan pada diri manusia yang menganggap bahwa itu obat untuk menghilangkan penyakit dalam tubuh. Padahal sembur utik itu sebagai pengingat kita bahwa suatu saat manusia itu akan menemui ajalnya dan tidak akan kembali lagi. Terkadang hal ini dilatar belakangi pula dengan keinginan manusia untuk mendapatkan ketenangan hidup.

Tujuan adanya tradisi sembur utik itu sendiri yang paling utama adalah mendapat keselamatan, maksudnya yakni agar segala balak atau malapetaka dibawa oleh yang meninggal. Tujuan keduanya yaitu menyemburkan berarti menyebarkan amalan atau kebaikan, tujuan ketiganya yakni untuk tetap mempertahankan adat istiadat atau tradisi yang memang sudah ada sejak zaman dahulu, sedangkan yang ke empat yakni pituduh lan piduduh orang zaman dahulu. Maksud dari pituduh lan piduduh yakni pemberitahuan kepada yang masih hidup bahwa kelak semua orang juga akan meninggal.

Dalam Pelaksanaan suatu tradisi pasti tentunya memiliki nilai yang nantinya dipergunakan untuk kehidupan sehari-hari. Nilai Psikologis : Berdasarkan uraian diatas dapat ditegaskan bahwa apabila sembur utik tidak dilaksanakan sebenarnya tidak apaapa, namun apabila seseorang meninggalkan satu syarat maka merasa bahwa kewajibannya belum terpenuhi serta tidak akan tenang karena arwah atau roh yang meninggal masih menghampiri, dengan alasan bawaan dari gedong peteng atau rahim belum sepenuhnya dibawakan. Nilai Religius : Dalam pelaksanaan tradisi sembur utik sebenarnya memiliki nilai religi, meski pada dasarnya hal tersebut tidak diperbolehkan dalam islam. Tetapi dalam hal ini nilai religi bisa kita ambil yakni dalam pengantaran jenazah ke kuburan dengan adanya sembur utik itu tadi. Adanya penyebaran sembur utik dalam pelaksanaannya sebenarnya selalu menyebutkan shalawat atas Nabi Muhammad ketika penyemburan beras kuning dan bunga, selain itu para pengiring jenazah lainnya juga membaca laa ilaahaillallah. Maksud dari pembacaan shalawat dan laa ilaahaillallah tadi sebenarnya agar kita selalu menginggat Allah dan rasulNya, dengan itu kita berarti berdzikir dan megingat akan kematian agar kita sebagai manusia tidak takabbur.

Nilai kearifan lokal : Dalam prosesi pelaksanaan tradisi sembur utik terdapat nilai kearifan lokal yang dapat di lestarikan, hal tersebut dapat dilihat dari guyub rukunnya para masyarakat yang hadir dan mengikuti prosesi tersebut. Para masyarakat saling bergotong royong untuk membuat sembur utik itu sendiri meskipun keluarga almarhum tidak mengkomandoi untuk membuatnya, serta para masyarakat rela untuk datang mengurus jenazah hingga ke liang lahat. Sebenarnya dalam islam hal ini juga dianjurkan dalam hal mengurus jenazah sebagaimana telah diriwayatkan Bukhari yakni segerakanlah penguburan jenazah, maka jika ia baik, maka baiklah yang kamu ajukan, dan jika ia selain dari itu, maka kejahatan yang kamu turunkan dari bahumu (HR. Bukhari-Muslim, al-Lu'lu wa al marjan, no.550 dalam Sholikhin, 2008:308).

Pandangan islam terhadap adanya tradisi sembur utik adalah haram, karena jelas hal tersebut membuang-buang atau memubadzirkan barang. Sejalan dengan pendapat tersebut dalam praktik persebaran Islam memasuki Jawa tetap tidak menghilangkan unsur-unsur lokal sebagai bentuk nilai luhur. bahwa nilai-nilai ajaran Islam yang tercermin di dalam al-Qur'an dan Hadis itu juga dapat ditransformasikan dalam kesenian lokal suatu masyarakat. Titik temunya terletak pada keindahan dan nilai luhur kearifan lokal. Oleh karena itu, dalam penyebaran Islam di Jawa beberapa gagasan yang mudah diterima dan diserap tanpa ada paksaan adalah dengan akulturasi. Besarnya kepercayaan animisme dan dinamisme, serta besarnya pengaruh Hindu dan Budha menjadikan konsep tasawuf (yang menekankan pada batin) menjadi sangat mudah untuk diterima. (Thoha, 2002:164-165).

Berbicara mengenai penggunaan bunga pada saat pengantaran jenazah ke 
kuburan, hal ini diperbolehkan apabila bunga diletakkan diatas kuburan atau makam si mayit, ini memiliki faedah atau manfaat. Lain halnya dengan penghamburan bunga dijalanan sepanjang jalan yang dilalui jenazah maka hal tersebut tidak ada faedah atau manfaatnya sama sekali bagi si mayit. Selain daripada itu penanaman bunga atau tumbuhan yang hidup juga di sunnahkan dan apabila selagi bunga itu hidup di atas makam si mayit, maka jangan sampai unga itu dicabut. Sejalan dengan hal itu ada pendapat lain yang menyatakan bahwa disunnahkan meletakkan pelepah daun yang masih hijau diatas kubur karena mengikuti sunah Nabi. Pelepah seperti itu dapat meringankan beban si mayat berkat bacaan tasbihnya. Untuk memperoleh tasbih yang sempurna, sebaiknya dipilih daun yang basah dan segar. Analog dengan meletakkan pelepah tadi ialah mengucurkan bunga atau sejumlahnya. Pelepah atau bunga yang masih segar tadi haram diambil karena menjadi hak si mayat. Akan tetapi, kalau sudah kering, hukumnya boleh lantaran sudah bukaan hak si mayat karena sudah tidak bertasbih lagi (Kasyf alsubuhat dalam Sholikin, 2010:98).

\section{KESIMPULAN}

Banyak yang tidak tahu mengenai asal usul tradisi sembur utik yang dilakukan di Desa Wonosobo dalam pengantaran jenazah. Karena dalam pelaksanaannya pun para masyarakat hanya ikut-ikutan, atau bahkan ada yang mengikuti wasiat dari orang tua zaman dahulu saja. Dalam pelaksanaannya ternyata sebenarnya dalam penyemburan sembur utik itu tadi haruslah mengucapkan shalawat atas Nabi Muhammad agar si mayit mendapatkan wasilahnya. Didalam tradisi sembur utik ternyata memiliki nilai-nilai yakni nilai psikologis, nilai religi, dan nilai kearifan lokal. Meskipun sebenarnya tradisi sembur utik tidak diperbolehkan, bukan berarti sepenuhnya tidak tidak boleh kita pakai dalam berkehidupan sehari-hari. Ada hal yang perlu kita lihat dan kita pergunakan dalam kehidupan sehari-hari, yakni guyun serta gotong royong dalam bermasyarakat. Tradisi sembur utik mengalami perubahan makna tatkala masyarakat mensalah artikan pemfungsian dari sembur utik. Makna yang seharusnya hanyalah sebuah pengingat akan kematian, menjadikan masyarakat memiliki keyakinan tentang hal tersebut sehingga menuju ke arah yang dilarang oleh Allah yaitu syirik atau menyekutukan selain Allah

\section{DAFTAR PUSTAKA}

Chafidh, M.Afnan. A.Ma"ruf Asrori. 2007. Tradisi Islam (Panduan Prosesi Kelahiran-Perkawinan-Kematian). Surabaya: Khalista.

Departemen Pendidikan dan Kebudayaan (DEKDIKBUD). 1989. Kamus Besar Bahasa Indonesia. Jakarta: Balai Pustaka.

Jamil, Abdul, Abdurrahman Mas"ud, Amin Syukur, dkk. 2002. Islam dan Kebudayaan Jawa.Yogyakarta: Gama Media.

Mursalin, Ayub. 2004. Cukuplah Mati Sebagai Penasehat. Jakarta: Mustaqim.

Pateda, Mansoer. 2001. Semantik Leksikal. Jakarta:Rineka Cipta.

Rendra. 1984. Mempertimbangkan Tradisi. Jakarta: PT. Gramedia.

Sholikin, Muhammad. 2010. Ritual \& Tradisi Islam Jawa. Yogyakarta : Narasi.

Sulistyani. 2015. Ritual Ider Bumi di Desa Kemiren, Kecamatan Glagah, Kabupaten Banyuwangi. MUDRA 22 (1) : 28-38.

Suwito. 2015. Tradisi dan Ritual Kematian Wong Islam Jawa. Jurnal Kebudayaan Islam. Vol. 13, No. 2, Juli - Desember 2015.

Van Gennep. 1977. The Rites of Passage. London: Pinguins. 